DOI: $10.19195 / 0080-3626.61 .2$

KATARZYNA KRZAK-WEISS

\title{
SUPLEMENT DO BADAŃ NAD POLSKIMI MODLITEWNIKAMI DRUKOWANYMI XVI WIEKU. PRÓBA IDENTYFIKACJI I CHRONOLOGIZACJI ARKUSZA ZE ZBIORÓW ARCHIWUM ARCHIDIECEZJALNEGO W GNIEŹNIE NA PODSTAWIE ANALIZY ZDOBIĄCYCH GO DRZEWORYTÓW
}

Charakterystyka ułomka znalezionego podczas prac inwentaryzacyjnych w Archiwum Archidiecezjalnym w Gnieźnie w tzw. luzach papierowych. Chronologizacja i identyfikacja znaleziska na podstawie analizy zdobiących go ilustracji. Dziedzice Marka Szarfenberga czy Maciej Szarfenberg? Hortulus animae czy Horae Beatae Mariae Virginis?

SŁOWA KLUCZOWE: Hortulus animae, Horae Beatae Mariae Virginis, modlitewnik dla osób świeckich, Dziedzice Marka Szarfenberga, Maciej Szarfenberg, polska grafika książkowa XVI wieku

Podczas prac inwentaryzacyjnych prowadzonych w ostatnich latach w Archiwum Archidiecezjalnym w Gnieźnie odkryto już niejedno bezcenne dzieło, którego albo dotąd w ogóle nie znano, albo już wiele lat temu uznano za bezpowrotnie zaginione ${ }^{1}$. Dość przywołać znaleziony krótko po rozpoczęciu katalogowania, a wcześniej traktowany jako przepadły w trakcie II wojny światowej ${ }^{2}$, egzemplarz Pontificale Romanum (Wenecja, Lucantonio Giunta 1520), który należał ongiś do biskupa włocławskiego (a później prymasa) Macieja Drzewickiego, o czym informują: superekslibris (z malowanym herbem) umieszczony na unikatowej oprawie druku oraz naklejony na verso okładki przedniej ekslibris będący najstarszym polskim datowanym znakiem własnościowym wykonanym

1 Prace te prowadzone są w ramach przyznanego w 2012 roku grantu na realizację projektu „Inwentaryzacja zasobu Biblioteki Katedralnej w Gnieźnie” kierowanego przez dra Piotra Pokorę, a finansowanego przez Ministerstwo Nauki i Szkolnictwa Wyższego z Narodowego Programu Rozwoju Humanistyki (nr 11H 120179 81).

${ }^{2}$ E. Chwalewik, Ekslibrisy polskie szesnastego i siedemnastego wieku, Wrocław 1955, s. $15-16$. 
techniką drzeworytową ${ }^{3}$. Sporą wagę mają też odnalezione podczas prac inwentaryzacyjnych fragmenty dwóch nieznanych dotąd druków powstałych w krakowskiej oficynie Jana Hallera ${ }^{4}$. Niebagatelną wartość przedstawiają również — choć zachowały się tylko we fragmentach — znaleziska wydobyte z okładzin Consiliów Nicolausa Bohiera (Lyon, Michael Parmentarius 1554) ${ }^{5}$, zwłaszcza zaś karty Rejowego dialogu Kota ze Lwem, których odkrycie potwierdziło wcześniejszą hipotezę Tadeusza Witczaka ${ }^{6}$. Z tej samej oprawy zostały wyciągnięte także arkusze, których sposób wytłoczenia, a nade wszystko elementy graficzne pozwalają je łączyć z Hortulusem powstałym w 1546 roku w oficynie Dziedziców Marka Szarfenberga, przyczyniając się tym samym do uaktualnienia dotychczasowego stanu badań nad tym modlitewnikiem? ${ }^{7}$.

Równie duże znaczenie ma kolejne odkrycie dokonane podczas inwentaryzacji gnieźnieńskich zasobów, tym razem w tzw. luzach papierowych, czyli zbiorze nieskatalogowanych przeróżnych fragmentów wydobytych jakiś czas temu $\mathrm{z}$ opraw znajdujących się w tamtejszej książnicy ${ }^{8}$. Wprawdzie jest to tylko poje-

3 Więcej o odkryciu: P. Pokora, „Pontificale Romanum” z 1520 roku z biblioteki prymasa Macieja Drzewickiego. O odnalezieniu jednego z zaginionych klejnotów Biblioteki Katedralnej w Gnieźnie, „Biblioteka” 2013, nr 17, s. 37-51. Odkrycie to dało z kolei asumpt do powstania pracy Arkadiusza Wagnera: Prymas Maciej Drzewicki jako bibliofil. W pięćsetlecie powstania pierwszego polskiego ekslibrisu (Warszawa 2016).

4 J. Łukaszewski, Fragmenty dwóch nieznanych druków z oficyny Jana Hallera (z 1506 i 1509 roku), ,Biblioteka” 2016, nr 20, s. 41-53.

5 Zob. J. Łukaszewski, W. Wydra, Fragmenty „Kota ze Lwem” Mikołaja Reja i innych druków z XVI w. odnalezione, Poznań 2016.

6 T. Witczak, Do genezy dialogu Kota ze Lwem, [w:] idem, Studia nad twórczością Mikołaja Reja, Warszawa-Poznań 1975, s. 231-249.

7 Zob. K. Krzak-Weiss, Suplement do badań nad tacińska edycja modlitewnika „Hortulus animae" (Kraków, Dziedzice Marka Szarfenberga 1546), [w:] Co musi wiedzieć uczony edytor nawet, jeśli nie chce. Prace ofiarowane Profesorowi Wiesławowi Wydrze, pod red. B. Hojdisa i K. Krzak-Weiss, Poznań 2017, s. 115-127. Spośród innych odkryć dokonanych podczas prac inwentaryzacyjnych w Archiwum Archidiecezjalnym w Gnieźnie warto również przywołać renesansową oprawę dzieła Jossego Clichtove'a Homiliarum (Kolonia 1535) — zob. R. Franczak, Oprawa ,Homiliarum" z petnopostaciowym wyciskiem radełka jagiellońskiego w zbiorach Archiwum Archidiecezjalnego w Gnieźnie, „Biblioteka” 2016, nr 20, s. 55-69; a także egzemplarz Opusculum Quadragesimale Walentego Wróbla (Lipsk, Melchior Lotter 1537) z zamieszczoną w nim dedykacją autora dla biskupa wileńskiego Pawła Holszańskiego, zakwestionowaną swego czasu przez Stanisława Estreichera — zob. M. Bartoszak, „Opusculum Quadragesimale” Walentego Wróbla $z$ dedykacja dla Pawła Holszańskiego, „Biblioteka” 2016, nr 20, s. 23-40.

8 Za informację o owym znalezisku oraz udostępnienie fotografii składam niniejszym gorące podziękowania Jakubowi Łukaszewskiemu. Wedle jego przypuszczeń tego konkretnego odkrycia dokonał zapewne ks. Władysław Zientarski, pełniący w latach 70. XX wieku funkcję dyrektora Archiwum Archidiecezjalnego. Niestety, nie wiadomo dokładnie, ani kiedy, ani z jakiej oprawy wydobyto ów arkusz. O znajdującej się w zbiorach gnieźnieńskiego Archiwum makulaturze (ale głównie rękopiśmiennej) pisała dotąd tylko Jadwiga Rył: Biblioteka Katedralna w Gnieźnie w latach 1650-1975, Lublin 1985, s. 65-66, przyp. 220-222; s. 67, przyp. 236. W tej chwili obiekt jest dopiero opracowywany, ale już wiadomo, że będzie skatalogowany pod sygnaturą PL 504. 
dynczy i mocno uszkodzony arkusz, ale wiele wskazuje na to, iż może on istotnie uzupełnić dotychczasowy stan badań nad polską typografią oraz piśmiennictwem religijnym I połowy XVI stulecia.

Znaleziony w zbiorach Archiwum Archidiecezjalnego fragment nierozciętego arkusza zawiera zaledwie 5 kart ze składki E, o czym zaświadcza odbita na jednej $z$ kart sygnatura $E_{2}$. W prawym górnym narożniku tej samej karty widnieje również foliacja (24), która zachowała się ponadto jeszcze tylko na jednej karcie, ale jej stan zachowania bardzo utrudnia odczytanie (najpewniej 23). Widać przy tym wyraźnie, iż niekompletność ułomka nie jest wyłącznie rezultatem zniszczenia spowodowanego upływem czasu, ale wynika również z przycięcia do rozmiarów oprawy, w której wykorzystano go jako materiał usztywniający9.

Całość została odbita czarną i czerwoną farbą drukarską, przy czym drugiej z nich uży to do wyróżnienia tytułów poszczególnych partii tekstu umieszczonych w żywej paginie (np. Ad sextam), sygnatur, foliacji oraz inicjałów, zarówno większych (wysokości dwóch wierszy) rozpoczynających akapity, jak i mniejszych (jednowierszowych) otwierających każde zdanie (il. 1,2). Tekst w języku łacińskim złożono pismem gotyckim (rotundą), w kolumnach jednołamowych liczących po 20 wierszy. Co ciekawe, na czterech z zachowanych kart widać wyraźnie, iż pewne ich partie (obejmujące 4-5 wierszy) złożono czcionkami o mniejszym stopniu, co uczyniono przypuszczalnie z potrzeby zmieszczenia tam większej partii tekstu. Rozmiary kart, mierzących ok. $100 \times 75 \mathrm{~mm}^{10}$, wskazują, iż druk, w którym miały się znaleźć, był formatu $16^{\circ}$.

$\mathrm{Z}$ uwagi na walory identyfikacyjne i chronologizacyjne bardzo cennymi elementami zachowanego arkusza są dwa zdobiące go drzeworyty: Pokłon Trzech Króli (k. $\left.\mathrm{E}_{2}\right)$ (il. 3) i Ofiarowanie w świątyni (k. $\left.\mathrm{E}_{3} \mathrm{v}\right)$ (il. 4). Obie ryciny mają identyczne rozmiary $(47 \times 36 \mathrm{~mm})$, a wyraźne podobieństwo stylistyczno-formalne pozwala na uznanie ich za dzieło tego samego artysty oraz założenie, iż stanowiły część większego zespołu ilustracyjnego. Drzeworyty cechuje delikatna, miękko prowadzona i wprawnie różnicowana kreska, cięta w sposób dowodzący niemałych umiejętności, niestety, anonimowego mistrza. Uwagę zwraca charakterystyczna podwójna linia, za pomocą której artysta oddaje krawędzie szat poszczególnych postaci. Wyróżnikiem jego prac jest wyraźna skłonność do zapełniania kreską całej przestrzeni pola obrazowego, uwidaczniająca się zwłaszcza w partii tła i niekiedy - jak zdradza to przedstawienie Ofiarowania w światyni - wpływająca negatywnie na czytelność sceny. Obie ryciny łączy ponadto wycięta na nich data „1533”, która jest niezwykle istotnym elementem chronologizacyjnym, wskazującym jednocześnie dokładny czas ich powstania, a także wyznaczającym terminus post quem wydrukowania analizowanego arkusza.

${ }^{9} \mathrm{Z}$ uwagi na spore uszkodzenie arkusza, wynikające zarówno z jego zniszczenia, jak i przycięcia, trudno podać jego dokładne pierwotne rozmiary. Obecnie w najszerszym miejscu mierzy on $206 \mathrm{~mm}$, w najwyższym zaś $197 \mathrm{~mm}$.

${ }^{10}$ Brak precyzji w wymiarowaniu kart wynika z ich zniszczenia i zniekształcenia. 


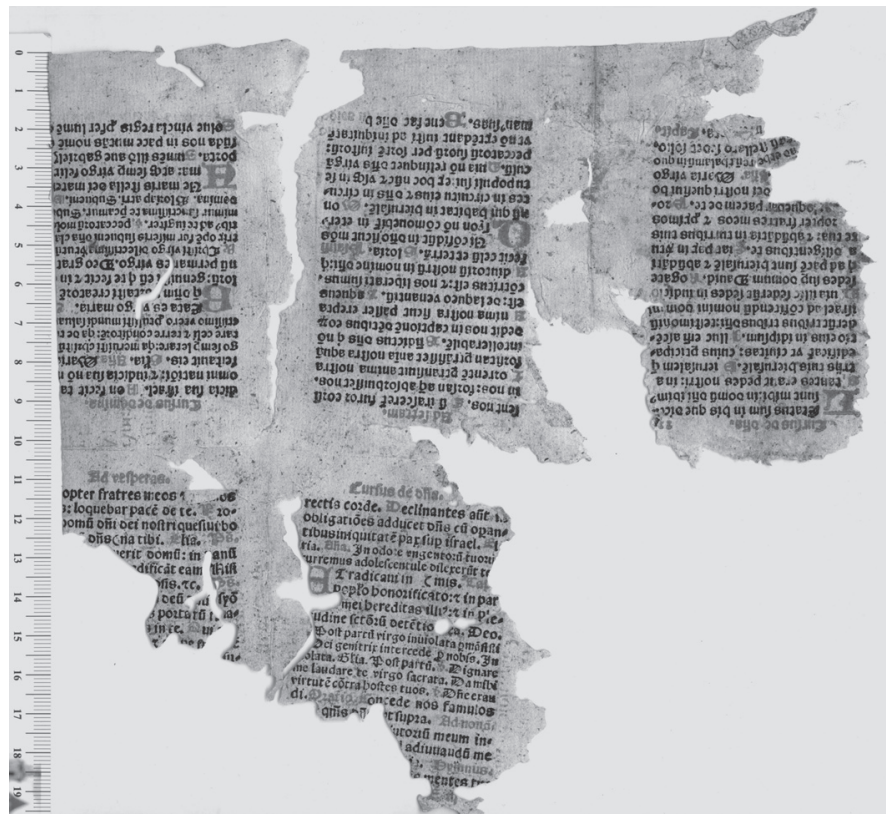

I1. 1. Arkusz znaleziony w Archiwum Archidiecezjalnym w Gnieźnie, sygn. PL 504 (zdjęcie udostępnione przez Jakuba Łukaszewskiego)

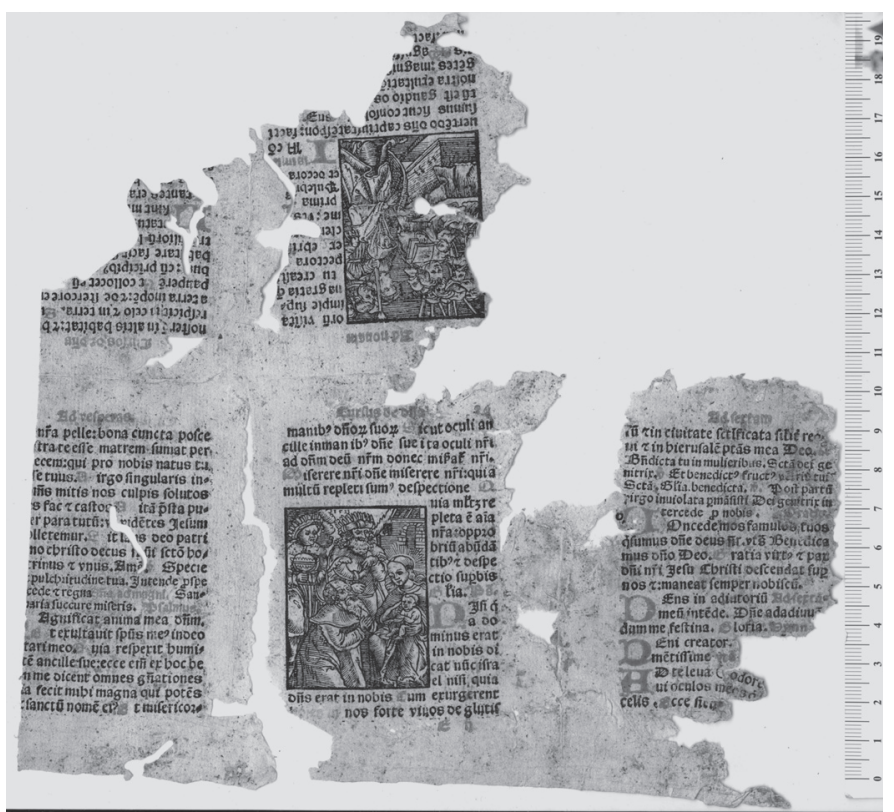

I1. 2. Arkusz znaleziony w Archiwum Archidiecezjalnym w Gnieźnie sygn. PL 504 (zdjęcie udostępnione przez Jakuba Łukaszewskiego) 


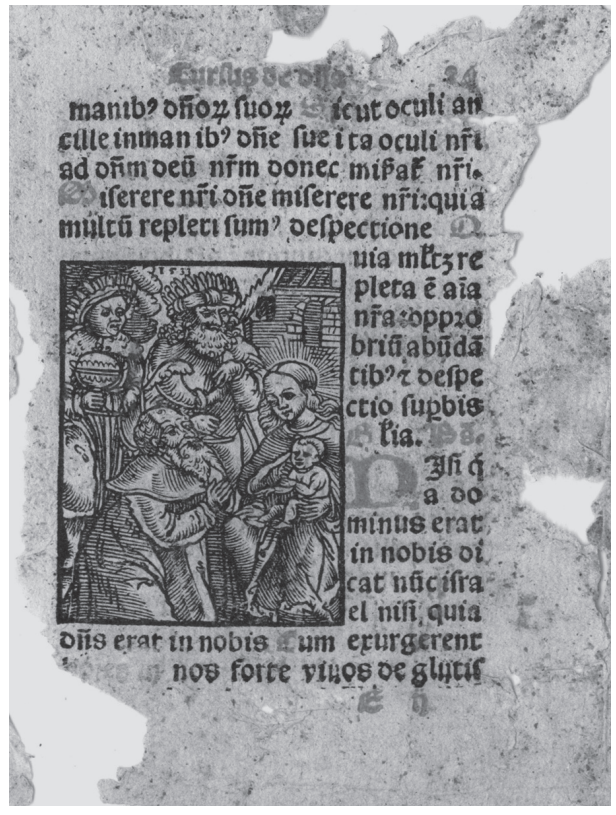

Il. 3. Karta $\mathrm{E}_{2}$ i zdobiący ją drzeworyt: Pokłon

Trzech Króli, Archiwum Archidiecezjalne w Gnieźnie, sygn. PL 504 (zdjęcie udostępnione przez Jakuba Łukaszewskiego)

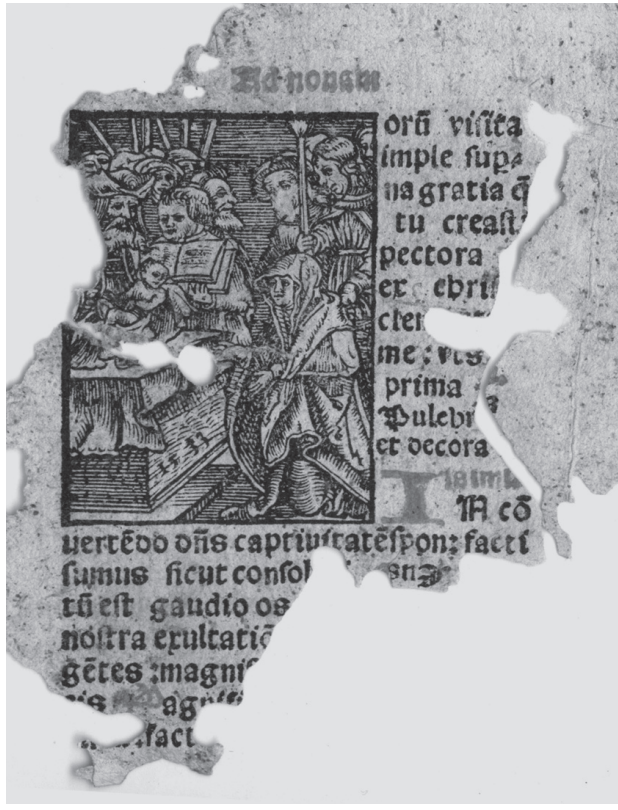

I1. 4. Karta $\mathrm{E}_{3} \mathrm{v}$ i zdobiący ją drzeworyt: Ofiarowanie w świątyni. Archiwum Archidiecezjalne w Gnieźnie, sygn. PL 504 (zdjęcie udostępnione przez Jakuba Łukaszewskiego)

Co więcej, zarówno data ta, jak i wskazane cechy stylistyczno-formalne pozwalają połączyć owe drzeworyty z innymi pracami, znanymi z druków krakowskich I połowy XVI wieku, zwłaszcza z rycinami z modlitewnika Hortulus animae wydanego w 1546 roku przez Dziedziców Marka Szarfenberga ${ }^{11}$. Wśród kilkudziesięciu zdobiących ów druk ilustracji są bowiem cztery (dwa różne przedstawienia Adoracji Dzieciątka oraz Nawiedzenie św. Elżbiety i Św. Brygida Szwedzka) ${ }^{12}$, których wymiary oraz sposób zakomponowania i wycięcia nie pozostawiają żadnych wątpliwości co do ich przynależności do tego samego zespołu graficznego, z którego pochodzą obie prace z gnieźnieńskiego arkusza.

Dla niniejszych rozważań szczególnie istotne jest jednak to, iż na jednej z kart Hortulusa (k. 199) widnieje ta sama rycina z Pokłonem Trzech Króli, jaka znajduje się w gnieźnieńskim znalezisku (il. 5). Jej obecność w druku wydanym przez Dziedziców jest zarówno potwierdzeniem sugerowanej wcześniej przynależności owej ryciny (a także drugiej, czyli Ofiarowania) do większego zespołu

${ }^{11}$ K. Krzak-Weiss, W ogrodzie duszy. Studia nad wyposażeniem graficznym polskich edycji modlitewnika „Hortulus animae”, Poznań 2014, s. 166, 224-242.

12 Wprawdzie zaznaczyć wypada, iż jedna spośród owych czterech prac - Św. Brygida Szwedzka - nie jest datowana, ale zarówno wymiary drzeworytu, jak i sposób jego wykonania pozwalają zaliczyć ją do tego samego zespołu. 


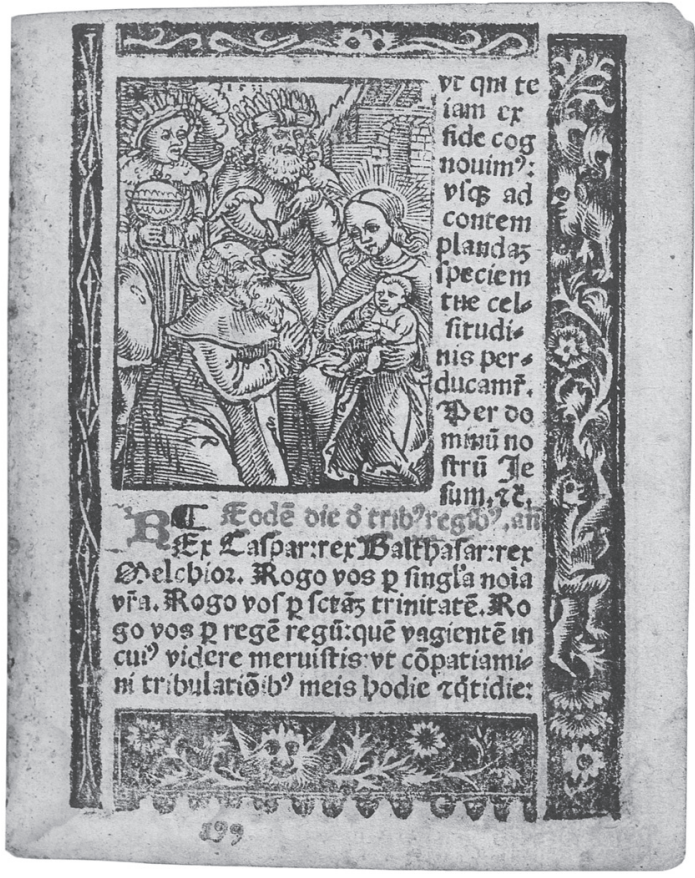

Il. 5. Karta 199 i zdobiący ją drzeworyt: Pokłon Trzech Króli; Hortulus animae, Kraków, Dziedzice Marka Szarfenberga 1546. Warszawa, Biblioteka Narodowa, sygn. SD XVI.O.6032

ilustracyjnego ${ }^{13}$, jak i kolejną niezwykle ważną wskazówką chronologizacyjną. Porównanie stanu zachowania obu odbitek pozwala bowiem założyć, iż arkusz odkryty w Archiwum wytłoczono przed Hortulusem, a zatem za terminus ante quem jego powstania uznać należy kwiecień 1546 roku, gdyż właśnie ta data widnieje w kolofonie modlitewnika (il. 6). I choć wnioskowanie na podstawie analizy tak skromnego materiału badawczego jest zawsze obarczone sporym ryzykiem błędu ${ }^{14}$, to wyraźne uszkodzenia prawej krawędzi ramki drzeworytu widoczne na odbitce zamieszczonej w druku Dziedziców, a nieobecne w analizowanym arkuszu, nie pozostawiają większych wątpliwości.

Ale czy obecność identycznej ryciny zarazem na ułomku ze zbiorów gnieźnieńskiego Archiwum i w Hortulusie Dziedziców z 1546 roku oznacza, że oba druki powstały w tej samej oficynie? Nie można tego wykluczyć, choć gdyby fak-

13 Konstatując dotychczasowe ustalenia, do zespołu tego należy zaliczyć: Pokłon Trzech Króli, Ofiarowanie w świątyni, Nawiedzenie św. Elżbiety, Św. Brygidę Szwedzka oraz dwa przedstawienia Adoracji Dzieciątka.

${ }^{14}$ Zawsze istnieje możliwość, iż badany obiekt był słabiej lub mniej dokładnie odbity i wówczas wniosek powstały na podstawie jego analizy mógłby okazać się nietrafny. Zob. H. Bułhak, Metoda typograficzna w badaniach nad dawna ksiązka. Uwagi i refleksje, „Biuletyn Poligraficzny" 1977 , nr 2, s. 41. 


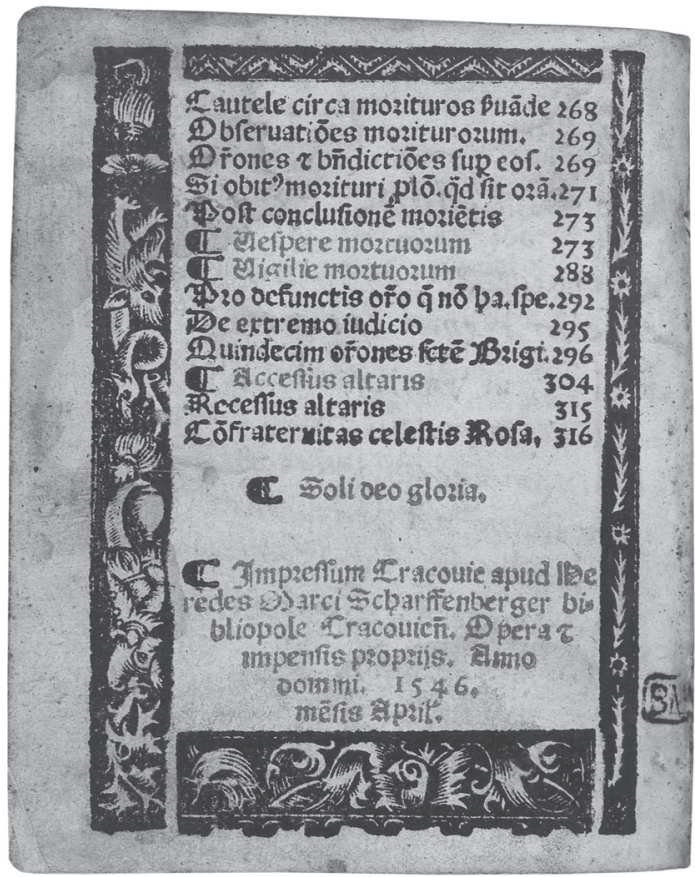

Il. 6. Kolofon; Hortulus animae, Kraków, Dziedzice Marka Szarfenberga 1546.

Warszawa, Biblioteka Narodowa, sygn. SD XVI.O.6032

tycznie tak było, to na wydanie owego arkusza spadkobiercy Marka Szarfenberga nie mieliby za dużo czasu. Jeśli bowiem wziąć pod uwagę fakt, iż ojciec Mikołaja i Stanisława, którzy stworzyli firmę pod szyldem Dziedziców, zmarł pod koniec $1545 \mathrm{roku}^{15}$, a Hortulus ozdobiony tym samym drzeworytem, co gnieźnieńskie znalezisko, powstał w kwietniu 1546 roku, to prace nad wytłoczeniem analizowanego arkusza - pamiętając o wcześniejszym ustaleniu, iż powstał on przed modlitewnikiem - musiałyby przebiegać nieomal równocześnie. Zważywszy zaś, jak bogatą szatę graficzną ma wzmiankowany Hortulus ${ }^{16}$, a zatem jak wiele wysiłku wymagało przygotowanie go do druku, trudno sobie wyobrazić, by w tym samym czasie zajmowano się również składem innej, także ilustrowanej publikacji.

A może gnieźnieński ułomek wcale nie powstał w oficynie Dziedziców, zbieżność drzeworytów wynika zaś z faktu, iż XVI-wieczne drukarnie nierzadko wymieniały się posiadanym materiałem graficznym, który po wykorzystaniu i uznaniu przez jednego typografa za już nieprzydatny był przezeń odsprzedawany

15 A. Kawecka-Gryczowa, A. Mańkowska, Szarfenberg Marek, [w:] Drukarze dawnej Polski od XV do XVIII wieku. T. 1, Małopolska. Cz. 1, Wiek XV-XVI, pod red. A. Kaweckiej-Gryczowej, Wrocław 1983, s. 253.

16 Więcej o szacie graficznej tego wydania Hortulusa — zob. K. Krzak-Weiss, W ogrodzie..., s. $161-167$. 
innemu? Dość przywołać tu choćby „wędrówkę” rycin, które najpierw ozdobiły Hortulus wydany przez Hieronima Wietora (1532/1533), a następnie zostały użyte w tym samym modlitewniku wytłoczonym przez Macieja Szarfenberga (1533) ${ }^{17}$. Wszak co do tego nie ma najmniejszych wątpliwości, że wykorzystane przez Dziedziców drzeworyty z wyciętą na nich datą „1533” nie mogły zostać przez nich zamówione, gdyż ich firma rozpoczęła swoją działalność dopiero ponad 10 lat później. Oznacza to, iż pierwszym właścicielem owego zespołu graficznego był na pewno ktoś inny. Pytanie tylko: kto?

Najbardziej prawdopodobne wydaje się, iż był nim Maciej Szarfenberg ${ }^{18}$ typograf działający w Krakowie od ok. 1527 do 1547 roku, o którym wiadomo, iż część należącego do niego materiału graficznego trafiła później do oficyny Dziedziców $^{19}$. Pewne jest również, iż w zasobach warsztatu Macieja znajdowała się przynajmniej jedna seria drzeworytów z wyciętą na nich datą „1533”, których użył do zilustrowania łacińskiej edycji Hortulusa wydanej przez niego w 1533 roku $^{20}$. Wprawdzie prace te nie są identyczne z tymi, które zachowały się na ułomku z Archiwum, ale łączy je z nimi tak wiele wspólnych cech stylistycznych, że nie można wykluczyć, iż oba zespoły graficzne powstały w tej samej pracowni i że stało się tak na zamówienie tego samego drukarza ${ }^{21}$. I choć to tylko hipoteza, ponieważ na razie nie udało się znaleźć żadnego druku, który wyszedł spod pras warsztatu Macieja i został zilustrowany pracami należącymi do serii znanej z ułomka, to nie można wykluczyć, iż takowy kiedyś istniał, ale do dzisiaj się nie zachował. A może owym drukiem był właśnie ten, z którego pochodzi arkusz odkryty w Gnieźnie?

Kolejną istotną kwestią, obok ustalenia czasu i miejsca powstania analizowanego zabytku, jest identyfikacja druku, którego był on częścią. Pewne jest, iż odkryty w Archiwum Archidiecezjalnym ułomek to fragment modlitewnika. Wskazują na to jednoznacznie obie ryciny, których ikonografia związana jest z życiem Maryi, a przede wszystkim treść obejmująca modlitwy należące do zespołu zatytułowanego Cursus de domina (na co wskazuje zapis umieszczony w żywej paginie), przy czym z wszystkich znajdujących się w nim pierwotnie oracji ułożonych w porządku godzin kanonicznych zachowały się tylko: Ad sextam, Ad nonam, Ad vesperas. Dokonując analizy porównawczej gnieźnieńskiego znaleziska z zachowanymi przykładami piśmiennictwa religijnego wydanymi w Krakowie

17 Ibidem, s. 131-139, 145-152.

18 A. Kawecka-Gryczowa, A. Mańkowska, Szarfenberg Maciej, [w:] Drukarze dawnej Polski..., s. 238-244.

19 Eadem, Dziedzice Marka Szarfenberga, [w:] Drukarze dawnej Polski..., s. 263.

20 Data „1533” (a na niektórych „1532”) widnieje na kilkunastu drzeworytach o wymiarach nieco większych $-65 \div 67 \times 50 \div 52 \mathrm{~mm}$ - od tych, jakimi odznaczają się ryciny znane z gnieźnieńskiego ułomka (K. Krzak-Weiss, W ogrodzie duszy..., s. 148-150, 208-222).

21 Wniosek ten oprzeć można na porównaniu rycin znajdujących się w obu zespołach, a przedstawiających Pokłon Trzech Króli oraz Św. Brygidę Szwedzką. 
w ustalonych wcześniej granicach chronologicznych, nie trudno dostrzec, iż najwięcej cech wspólnych łączy go ze wspomnianym już wcześniej Hortulusem. I nie jest to tylko kwestia obecności takiej samej ryciny z przedstawieniem Pokłonu Trzech Króli, lecz także inne, niejednokrotnie równie daleko idące podobieństwa. Dotyczy to zwłaszcza tekstu, który w wielu partiach jest niemal (bo niekiedy różni się abrewiaturami) identyczny z zawartym na kartach modlitewnika wydanego w 1546 roku przez Dziedziców Marka Szarfenberga ${ }^{22}$. Mogłoby się więc wydawać, że z racji owych zbieżności nie powinno być wątpliwości co do tego, iż znaleziony w Archiwum fragment arkusza po sfalcowaniu miał być częścią Hortulusa, a konkretniej — znajdującego się w nim Cursus Beatae Mariae Virginis. Skąd zatem ów brak pewności?

Problem tkwi w drugiej z zachowanych w gnieźnieńskim ułomku rycin oraz rozlokowaniu obu drzeworytów w obrębie tekstu. Rzecz w tym, iż motyw Ofiarowania $w$ światyni nie należał do stałych elementów wyposażenia graficznego Hortulusów. Wprawdzie to, iż nie ma go w edycji z 1546 roku, jeszcze o niczym nie przesądza, albowiem żaden z jej zachowanych egzemplarzy nie jest kompletny i wobec tego nie daje pewności, że owej ryciny w nim pierwotnie nie było. Nie ma go w nieomal kompletnym wydaniu Macieja Szarfenberga z 1533 roku, ale pojawia się w Hortulusach wytłoczonych przez Mikołaja Szarfenbergera (1585) oraz Andrzeja Piotrkowczyka (1636) ${ }^{23}$. Tyle że w obu tych edycjach Ofiarowanie nie towarzyszy modlitwom z zespołu Cursus de domina, lecz Modlitwom o świętach uroczystych $^{24}$. Zresztą podobnie jest też w wypadku wspomnianego już Pokłonu Trzech Króli, który w Hortulusie z 1546 roku nie ozdobił Cursus Beatae Mariae Virginis (nota bene całkowicie pozbawionego ilustracji), lecz właśnie Orationes de principalioribus festis. Wniosek stąd taki, iż tekst widniejący na znalezionym ułomku jest wprawdzie nieomal identyczny z tym, jaki został wytłoczony w Hortulusie Dziedziców z 1546 roku, ale sposób jego zilustrowania jest całkowicie odmienny. I co więcej, nie wskazuje wcale na Hortulus animae, ale na Horae Beatae Mariae Virginis. Ów drugi z popularnych w XVI stuleciu (a znany był już od XIII wieku ${ }^{25}$ ) modlitewników nie tylko posiadał bardzo podobny do Hortulu$s a$ program modlitewny, w którym znajdowały się m.in. podzielone na godziny oracje do NMP, ale ponadto wyobrażenie Pokłonu Trzech Króli i Ofiarowania $w$ światyni należało do stałych elementów jego programu ikonograficznego. Co więcej, oba przedstawienia ilustrowały w Horae właśnie oficjum do NMP. Według najczęściej powtarzającego się schematu Pokłon towarzyszył w nim sekście, a Ofiarowanie nonie, czyli analogicznie jak ma to miejsce w ułomku z gnieźnień-

22 Dla przykładu tekst znajdujący się na karcie $\mathrm{E}_{2}$ gnieźnieńskiego ułomka (Sicut oculi ancille...) w Hortulusie Dziedziców widnieje na karcie $\mathrm{C}_{3} \mathrm{v}$.

23 Ibidem, s. 259, 272, 278, 293.

24 Tam również znalazł się w obu edycjach Pokłon Trzech Króli (ibidem, s. 259, 272, 278, 293).

25 Ibidem, s. 18-25 (zob. bibliografia na temat tego modlitewnika). 
skiego Archiwum ${ }^{26}$. Czyżby zatem był on fragmentem Godzinek? Jeśli tak, to byłby wówczas częścią zupełnie nieznanego dotąd wydania tego modlitewnika, jakie wyszło spod pras polskiej oficyny w I połowie XVI wieku.

Czy jednak faktycznie tak było? Tego na podstawie jednego, na domiar niepełnego, arkusza nie sposób bezsprzecznie ustalić. Można jednak mieć nadzieję, iż gdzieś, w zakamarkach jakiegoś archiwum kryją się jeszcze kolejne fragmenty tego samego druku, które pozwolą na jego bezsporną identyfikację.

\section{KATARZYNA KRZAK-WEISS}

A SUPPLEMENT TO THE STUDY OF POLISH PRAYER BOOKS PRINTED IN THE 16TH CENTURY. AN ATTEMPT TO IDENTIFY AND ESTABLISH THE CHRONOLOGY OF A SHEET FROM THE COLLECTION OF THE ARCHDIOCESAN ARCHIVES IN GNIEZNO ON THE BASIS OF ITS WOODCUT DECORATIONS

\section{Summary}

The article is an attempt to identify a single, much damaged sheet discovered during inventory taking at the Archdiocesan Archives in Gniezno. An analysis of this historical specimen, especially its graphics content, has made it possible to establish that it is a fragment of a hitherto unknown Latin prayer book published in Kraków between 1533 and 1546.

KEY WORDS: Hortulus animae, Horae Beatae Mariae Virginis, prayer book for the laity, The Heirs of Marek Szarfenberg, Maciej Szarfenberg, Polish 16th-century book graphics

26 U. Borkowska, Królewskie modlitewniki. Studium z kultury religijnej epoki Jagiellonów (XV i początek XVI wieku), Lublin 1999, s. 34-36 (tu zob. bogata bibliografia na temat ikonografii Godzinek). 